\title{
Research on Influencing Factors and Evaluation System of Strategy Formulation Based on Internal Capabilities of Enterprises
}

\author{
Haixu Song ${ }^{1, a,{ }^{*}}$, Xiaodong $\mathrm{Li}^{1, \mathrm{~b}}$ and Rui $\mathrm{Li}^{1, \mathrm{c}}$ \\ ${ }^{1}$ State Grid Energy Research Institute Co., Ltd, SGCC Administrative Area, Future Science and \\ Technology Park North Area, Beqijia Town, Changping, Beiqijia, P. R. China \\ ashxstudent@126.com, ${ }^{b}$ lixiaodong@sgeri.sgcc.com.cn, ${ }^{\mathrm{C}}$ lirui@sgeri.sgcc.com.cn \\ ${ }^{*}$ Corresponding author
}

Keywords: Enterprise strategy, internal capabilities, influencing factors, evaluation system

\begin{abstract}
Based on the research results at home and abroad, this paper studies the influencing factors and evaluation system of strategy formulation from the perspective of internal capabilities. According to the research, in the process of strategy formulation and adjustment, except for the environmental change factors, enterprises should pay attention to internal resources and capacity factors, including scale strength, operating capability, management capability and innovation capability, to promote enterprises make scientific strategic decisions. This paper provides theoretical support and application tools for enterprises to improve their strategic management level and enhance their sustainable development capabilities.
\end{abstract}

\section{Introduction}

At present, with the high-quality development of the economy and the rapid development of science and technology, the environment is becoming more and more complex. It requires enterprises to make scientific strategies or adjustments adapt to changes and achieve sustainable development.

Research on the influencing factors of corporate strategy development has always been the focus of academic circles. Ansoff (1965) proposes that the strategic composition is mainly influenced by four factors, namely product and market scope, growth vector, synergy and competitive advantage. Haksnsson and Snehota (1989) establish a network model that argues that corporate strategy is formed in a complex network, including suppliers, competitors, and customers. Wernerfelt (1984) proposes that internal resources of enterprises have important significance for profitability and maintaining competitive advantage, and have a decisive role in optimizing strategies and creating market advantages. Zhao (2001) believes that the key to strategy formulation is whether the enterprise has the conditions to achieve strategic objectives, which are the organizational structure division, job setting and analysis, performance appraisal mechanism, incentive mechanism and the construction of senior management of the enterprise. Chen and Sheng Yan (2004) believe that the environment for enterprise development is important, but this is only a prerequisite for enterprise development. The key is the formation of the core competitiveness.

Generally speaking, the current research on the influencing factors of corporate strategy formulation has achieved rich results. Many scholars believe that the external environment and internal conditions are important factors impacting on strategy formulation. However, for the study of internal factors, there is no systematic evaluation system and evaluation method. In view of this, based on the existing research results, this paper studies the influencing factors and evaluation system of strategy formulation from the perspective of internal capabilities of enterprises, which can provide theoretical support and application tools for enterprises to improve their strategic management level and enhance their sustainable development capabilities.

\section{Analysis of Internal Influencing Factors in Enterprise Strategy Formulation}

Strategy formulation is the process that an enterprise determines its development direction and development goals based on environmental changes and its own strength. The formulation of 
corporate strategy is mainly influenced by two factors: the external environment and internal capabilities. Among them, the external environment contains opportunities and challenges for enterprise development, requiring enterprises to timely grasp or respond to major changes in the situation. Internal capabilities are an important cornerstone for enterprises to seize strategic opportunities, and are the basis for corporate strategy formulation. For internal capabilities, the factors affecting the formulation of corporate strategy mainly include four aspects: scale strength, operating capability, management capability and innovation capability.

(1) Scale strength

The comprehensive strength that the company currently possesses is the basis for the company to formulate its future development strategy and also the boundary for strategic arrangements. The development strategy of the enterprise must match the strength of its own. It can not be separated from the actual situation, arranging in a high-distance manner beyond its own ability. It should not be too conservative, which may make resources idle and miss good development opportunities. Therefore, scale strength is the basic premise of corporate strategy formulation.

(2) Operating capacity

Operating capacity mainly refers to the ability of an enterprise to invest, operate and ultimately receive remuneration for its business operations. Companies Only with strong capital return and profit levels can achieve sustainable development. At the same time, strong operating capabilities also mean that companies not only have good financial performance, but also have good development prospects and potential in the future. These are important foundations for corporate strategy development.

(3) Management capability

The management mode of an enterprise is related to the future development of the enterprise. After the strategic positioning and strategic objectives of the enterprise are determined, the key lies in execution and management. Business operations involve shareholders, creditors, upstream and downstream enterprises, society and other stakeholders. The development environment is complex, which puts forward higher requirement for the leadership to carry out good resource allocation and organizational coordination. A good management system and mechanism will help enterprises to formulate more ambitious strategic goals and achieve better performance.

(4) Innovation capability

Innovative ability is an important ability to measure whether a company can have core competitiveness and whether it can lead the industry. Strong innovation ability can provide inexhaustible motivation for the company's future strategic arrangements. At the same time, the innovation system and related institutional mechanisms, as well as the employee's innovative vitality and enthusiasm are also important aspects of innovation ability.

\section{Evaluation system construction of Internal Influencing Factors in Enterprise Strategy Formulation}

\subsection{Construction principle}

The evaluation system of the influencing factors of enterprise strategy formulation is composed of a series of indicators of different dimensions. It is an organic whole that can comprehensively reflect the internal capabilities influencing the formulation of corporate strategies. In order to improve the scientific and rationality of the evaluation system, the following principles should be followed in the construction of the evaluation system:

(1) Systematic principles. The systemic principle refers to a comprehensive grasp and analysis of internal capabilities as a whole. It is necessary to consider the internal resources and conditions of the enterprise fully so that the indicator system is comprehensive without repeating each other.

(2) The principle of importance. There are many internal capabilities that can affect the formulation of corporate strategies, but only the important and representative indicators are included.

(3) The principle of simplicity. For the evaluation system, it is necessary to be simple and practical. Too complicated ones can reduce its usability and practicability. 


\subsection{Evaluation system construction}

According to the internal influence factors impacting on enterprise strategy, the content of each dimension is analyzed to form an evaluation index system.

Scale strength includes income scale and asset size. Among them, the income scale refers to the overall scale of the company's operating income, and the asset size refers to the overall size of the enterprise in terms of assets. The world-class companies at home and abroad are often powerful companies with big assets sizes or income scales.

Operating capability includes profitability, operational efficiency, growth ability, and solvency. Among them, profitability refers to the ability of enterprises to obtain income through the allocation and operation of assets and capital. Operational efficiency refers to the ability to control costs such as operating costs, labor costs, management costs, and financial costs. Growth ability refers to the growth of the company and its development prospects. Solvency refers to the ability of an enterprise to repay long-term debt and short-term debt with its assets, mainly reflecting the financial security of the enterprise.

Management capability includes strategic decision-making capability, resource allocation capability, organizational coordination capability and mechanism support capability. Among them, strategic decision-making ability refers to the degree of leadership's emphasis on strategy, as well as the ability to judge the strategic situation accurately and make strategic decisions appropriately. The resource allocation capability refers to the ability of the enterprise to optimize the allocation of core resources such as people, finances, and materials. Organizational coordination capability refers to the ability to coordinate between different departments, different levels, and different businesses. Mechanism support capability refers to the ability to establish institutional mechanisms that are compatible with the new strategy. The level of management tools refers to the ability to learn and apply information technology or advanced tools that can improve management efficiency.

Innovation capability includes innovation investment, application of innovation results, and innovation atmosphere. Among them, innovation investment refers to the degree of investment in research and development. The application of innovation results refers to the ability to achieve innovative results in patents, standards, etc., and the ability to translate innovation into industry. The innovative atmosphere refers to the innovation system and related institutional mechanisms, as well as the employee's innovative vitality and enthusiasm.

Table 1. Evaluation system of Internal Influencing Factors in Enterprise Strategy Formulation

\begin{tabular}{|c|c|c|}
\hline Influencing factors & Sub-dimension & Main contents \\
\hline \multirow{2}{*}{ Scale strength } & Income scale & Overall scale of the company's operating income \\
\hline & Asset size & The overall size of the asset \\
\hline \multirow{4}{*}{ Operating capacity } & Profitability & $\begin{array}{l}\text { The ability of enterprises to obtain income through } \\
\text { the allocation and operation of assets and capital. }\end{array}$ \\
\hline & operational efficiency & $\begin{array}{l}\text { The ability to control costs such as operating costs, } \\
\text { labor costs, management costs, and financial costs }\end{array}$ \\
\hline & Growth ability & $\begin{array}{l}\text { The growth of the company and its development } \\
\text { prospects }\end{array}$ \\
\hline & Solvency & $\begin{array}{l}\text { The ability of an enterprise to repay long-term debt } \\
\text { and short-term debt with its assets, mainly reflecting } \\
\text { the financial security of the enterprise }\end{array}$ \\
\hline \multirow{4}{*}{ Management capability } & $\begin{array}{l}\text { Strategic } \\
\text { decision-making } \\
\text { capability }\end{array}$ & $\begin{array}{l}\text { The degree of leadership's emphasis on strategy, as } \\
\text { well as the ability to judge the strategic situation } \\
\text { accurately and make strategic decisions } \\
\text { appropriately }\end{array}$ \\
\hline & $\begin{array}{l}\text { Resource allocation } \\
\text { capability }\end{array}$ & $\begin{array}{l}\text { The ability of the enterprise to optimize the } \\
\text { allocation of core resources such as people, } \\
\text { finances, and materials. }\end{array}$ \\
\hline & $\begin{array}{l}\text { Organizational } \\
\text { Coordination } \\
\text { Capability }\end{array}$ & $\begin{array}{l}\text { The ability to coordinate between different } \\
\text { departments, different levels, and different } \\
\text { businesses }\end{array}$ \\
\hline & $\begin{array}{l}\text { Mechanism support } \\
\text { capability }\end{array}$ & $\begin{array}{l}\text { The ability to establish institutional mechanisms that } \\
\text { are compatible with the new strategy }\end{array}$ \\
\hline
\end{tabular}




\begin{tabular}{lll}
\hline & $\begin{array}{l}\text { The level of } \\
\text { management tools }\end{array}$ & $\begin{array}{l}\text { The ability to learn and apply information } \\
\text { technology or advanced tools that can improve } \\
\text { management efficiency }\end{array}$ \\
\hline Innovation investment & $\begin{array}{l}\text { Mainly refers to the degree of investment of } \\
\text { enterprises in research and development }\end{array}$ \\
\hline $\begin{array}{l}\text { Application of } \\
\text { innovation results }\end{array}$ & $\begin{array}{l}\text { Mainly refers to the ability to achieve innovative } \\
\text { results in patents, standards, etc., and the ability to } \\
\text { transform innovation into industry. }\end{array}$ \\
\cline { 2 - 4 } & $\begin{array}{l}\text { Innovation system and related institutional } \\
\text { Innochanisms, employee innovation vitality and } \\
\text { innovation enthusiasm }\end{array}$ \\
\hline
\end{tabular}

\section{Conclusion}

Based on the research results at home and abroad, this paper studies the influencing factors and evaluation system of strategy formulation from the perspective of internal capabilities. According to the research, in the process of strategy formulation and adjustment, except for the environmental change factors, enterprises should pay attention to internal resources and capacity factors, including scale strength, operating capability, management capability and innovation capability, to promote enterprises make scientific strategic decisions. This paper provides theoretical support and application tools for enterprises to improve their strategic management level and enhance their sustainable development capabilities.

\section{Acknowledgment}

This research was financially supported by the Science and Technology Project of SGCC "Research on Construction of Strategic Goal System and Key Technology of Strategy Implementation for SGCC in the New Era".

\section{References}

[1] H. Ansoff. The firm of the future. Harvard Business Review, vol. 43(5), pp. 163-178, 1965.

[2] H. Hakansson and I. Snehota. No business is an Island: the network concept of business strategy. Scandinavian Journal of Management, vol. 4, pp. 187-200, 1989.

[3] L. F.Wilkinson and W. J. Jhnston. Managing in complex business networks. Industrial Marketing Management, vol. 33(3), pp. 175-183, 2004.

[4] W. M. Zhao. Analysis of the strategic planning and basic management of private enterprises. Management Modernization, vol.2, pp. 12-13, 2003.

[5] F. Y. Chen and Y. C. Sheng. Strategic Choice of Technological Progress in Private Enterprises. Systems Engineering, vol. 9, pp. 38-41, 2004.

[6] X. Q. Chai. Analysis of the factors influencing the choice of competitive strategy. Business Research, vol. 5, pp. 11-13, 2002. 